\title{
Socio-political Dimension of the Islamic Umma
}

\author{
ANNA ZASUŃ \\ DR
}

Akademia im. Jana Długosza w Częstochowie, Wydział Filologiczno-Historyczny

a.zasun@ajd.czest.pl

Keywords

umma, Islam, religion, politics, state, nation, identity, community, togetherness

Abstract

The objective of the article is an attempt at answering the question whether the Islamic umma, being a socio-political phenomenon, refers to the conception of such a community as a nation or is it rather a religious community. Were there any other criteria outside Islam determining an Islamic identity. In her article, the authoress discusses the historic roots of the development of umma, the meaning of the concept itself in relation to the Quran and to the tradition, religious, social, and political factors influencing its specificity and finally on the transformation in the umma sense in our times. The article discusses several extensive issues, such as the relationship between umma and the state, the society and the authority in the historical state of Islam, the idea of umma in contemporary conditions, which are just mentioned, but refer to vital issues connected with what is often described as political Islam.

\section{Społeczno-polityczny wymiar islamskiej ummy}

Słowa kluczowe umma, islam, religia, polityka, państwo, naród, tożsamość, wspólnota, społeczność

Abstrakt

Celem artykułu jest próba odpowiedzi na pytanie, czy islamska umma, będąc fenomenem społeczno-politycznym, nawiązuje do koncepcji wspólnoty, jaką jest naród, czy raczej stanowi wyłącznie religijną zbiorowość, albo czy poza islamem istniały inne kryteria określające muzułmańską tożsamość? Autorka przedstawiła w artykule historyczne podłoże powstania ummy, znaczenie samego pojęcia w nawiązaniu do Koranu i do tradycji, uwzględniła również religijne, społeczne i polityczne czynniki wpływające na jej specyfikę, a ostatecznie także na przemianę w rozumieniu ummy współcześnie. Artykuł porusza kilka obszernych tematów, takich jak związek ummy z państwem, społeczeństwo i władza w historycznym państwie islamu, idea ummy w warunkach współczesnych, które zostały jedynie zasygnalizowane, stanowią jednak istotne kwestie połączone z tym, co często określa się mianem ,politycznego islamu”. 


\section{Introduction}

There are many criteria, which define an identity of an individual, apart from the biological or psychological ones. They include also cultural, social or socio-political factors (e.g. a nation, an ethnic group). In the West, it is assumed, according to the popular belief, that the most primary natural criterion of an identity of an individual related to a larger social group is a nation, whereas the factors holding individuals together within a nation are in general belief the ties of blood relationship (as we inherit our national status from our parents). It is also the language (a nation is sometimes defined as an "ethnic language community") and common territory, which "conditions the community of historical tradition and the feeling of psychological and cultural closeness" (Wojtaszczyk, Jakubowski, 2007, p. 179). Apart from the abovementioned aspects of common national identity, which could be described as objective aspects, we include also common habits and culture, within which the uniting elements for a group include the shared values, tradition, and customs as well as religion. In the contemporary geopolitical situation, in view of the process of integration and globalisation, it is rather difficult to talk about wholly homogeneous nations, in which the criterion, say exclusively cultural, i.e. common language, religion, history and tradition would be adequate. Nowadays, it is difficult to talk about one, objective pattern of a nation (Heywood, 2008, p. 245). Subjective factors, which determine a national community include development of a sense of national identity, including the conviction of individuals that they form a national community (Wojtaszczyk, Jakubowski, 2007, p. 180). In terms of politics, a nation is a group of people, who recognize themselves as members of a natural community, express their desire to establish or maintain their statehood and have civic awareness, which is a kind of a political awareness of being part of a nation (Heywood, 2008, p. 246). A nation as a political being derives from the European tradition, hence its meanings refer primarily to this cultural context, and apart from then allude to the Judeo-Christian, Greek and Roman traditions (Kitab, 2004, p. 85-86; Burgoński, Gierycz, 2014, p. 83). Can such a concept of community as a nation correspond to the Islamic form of a socio-political structure as umma? In order to answer such a question, the authoress presents specific traits of a Muslim community, taking into account its historical background, religious and socio-political nature as well as its transformation in the contemporary world. Undoubtedly, this issue was and still is the object of interest of political scientists, researchers of international relations, Orientalists including Arabists, as well as specialists in religious studies.

Among the complex literature dedicated to the issues of Islam and Muslims in the bygone ages and in the contemporary world, the analysis presented in the article is focused on the issues, which can be jointly referred to the problems of the so called political Islam. This notion often hides two competitive points of view: The first one admits that the political Islam and the religion of Islam are identical, as Islam is basically a political phenomenon in its nature, therefore, it is both a religion as well as a political ideology, whereas the other point of view assumes that Islam is a religion and as such it must be interpreted separately from the modern phenomenon, such as political Islam or Islamic political ideology, which is also called Islamic fundamentalism. Publications of such researchers as Bassam Tibi, William Montgomery Watt, Peter Mandaville, 
Mohammed Ayoob, Bernard Lewis, Graham Fuller, Olivier Roy, Nicholas P. Roberts or John L Esposito, quoted in the paper cover both of the abovementioned points of view and this is why they facilitate interpretation of umma from the religious as well as socio-political perspective.

The subject of the analysis presented in the article is the Islamic umma, i.e. a Muslim community, whose identity is based on cultural foundations, first of all religious, but political as well. In modern conditions, forms of collective identity unite mainly, as it was mentioned above, with a nation or with an ethnical group. In Islam, the factor determining common affiliation is umma. The collective identity of members of the community concerns those who are members of the Muslim community of the faithful, i.e. the world of Islam, dār al-islām, described as "one of us", next to whom there is a community of "aliens", the so called non-Muslim world also referred to as the world of war, dār al-harb. It changed in history - sometimes the religious aspect was of fundamental importance, at other times, it was the socio-political factor (Linjakumpu, 2012, p. 18). Identity and unity of a community always means a form of homogeneousness, which occurs within the community, and any dissimilarity is connected rather with the heterogeneity existing in the world surrounding the group. Islamic identity can be particularly understood when we assume that cultural-socio-political dissimilarity that surrounds it is a variable context element, whereas the identity itself is a certain kind of constant. In the majority of Muslim countries, Islam still remains the most acknowledged, and in the decisive periods, it was even the sole source of self-determination and authority, and it concerns allegiance to umma, division into "one of us" and "alien". Religion is here "the first and fundamental identity, this is why these communities are defined rather from the point of view of Islam than from the point of view of an ethnical factor, language or state" (Lewis, 1991, p. 4). In this respect, the Muslim community is a unique social, cultural, as well as political phenomenon. In every respect of life of the Muslims, Islam offers the most extensive and clearly formulated ideology, standards and principles of cohabitation based on the Quran and the religious law szari'i. Moreover, it provides the most effective system of symbols for the Muslim community, which guarantees social and most of all political mobilisation. One should remember, however, that the social and political mobilisation as well as loyalty resulting from religion is not restricted in Islam to fundamentalism or Islamic revolutionaries, as they are not the only manifestations of faith and respect for tradition (Lewis, 1991, p. 3).

Historically umma was formed along with the development of the new religion of Islam on the lands of the Arabian Peninsula and provided foundations for a new Arab-Muslim state. The first organizer of a Muslim community was Muhammad, first of all during his activity in Medina, where he acted not only as a Prophet, as he did during his stay in Mecca, but mainly as a politician, statesman, diplomat and leader. The difficult task of the early years of managing the community of Medina was unification and development of the community of the fellow-brothers. Due to his own leadership skills as well as to his authority, he managed to head off the inter-tribal disputes that had been taking place in Medina for a long time, consolidate a group of ansārs (supporter from Medina, who entertained Muhammad offering him their loyalty and fidelity) with Muhajiruns (the ones that left Mecca with him) as well as overcame tribal nationalism, deeply rooted among the ancient Arabs (Bielawski, 1973, p. 50-51). The result of these actions was 
formation of a Muslim community umma, which was to take place of the former tribe kabila (Bielawski, 1973, p. 51). During the early years of the existence of the community, it was headed by Muhammad, who was both its political leader, leader and Prophet and legislator. Even then this primitive Muslim community used a kind of constitution, passed in Medina probably in the year 627 and recognised as the first political document. It is called the Constitution of Medina (in Arabic Suhuf al-Madina or shortly kitab). It regulated the lives of all the inhabitants of the city of the Prophet and it "demonstrating a philosophy of political power and authority not based on domination and subordination but on voluntary consent and allegiance" (Roberts, 2015, p. 147). With the formation of umma, which was often identified with the entire city-state or Islamic state, organisation of the community was to be supra-tribal, based on the new and sole ideology, which was Islam. While in the early period of its development, approximately until the rule of the Abbāsid dynasty, the beginning of which is in the year 750, the notion of umma pertained solely to the Arab tribes, with the passing of time the community became multiethnic and multiracial (Burgoński, Gierycz, 2014, p. 68). The brotherly community of umma became the basis of a typically Islamic social and political organization, which extended beyond the narrow frame of solely Arabic identity. According to Janusz Danecki, on the foundations of the idea of one God, which was something completely new in the conditions of the former Arabia (if the presence of Jews and factions of Christianity in the area are excluded), an idea that was unknown to Arabs of the al-jahiliyyah (pre-Islamic) period was born. In the community of the faithful that was set up by Muhammad, the basic value uniting members of the community became their faith in one god Allah, which was in a sense revolutionary in that tribal society, "Since instead of the tribal, hence limited, loyalty, an idea of a sovereignty of a social group was forming, of a theoretically unlimited range. A transition was taking place from a tribal society to a theocratic, feudal state" (Danecki, 2015, p. 94). In his pact concluded with Medina called its population the nation led by Allah, because any power comes from God. The idea can be found in the Quran, e.g. "O God, Owner of Sovereignty. You grant sovereignty to whom You will, and You strip sovereignty from whom you will. You honor whom you will, and You humiliate whom you will. In Your hand is all goodness. You are Capable of all things" (Quran III: 26). The former blood ties, the foundation of social and political organization of Arab tribes were replaced by religion (din), in which all people were equal before Allah (Bielawski, 1973, p. 48-49). Development of umma was the basis of further political activity of Muhammad, including the one focused on its intensive spreading, originally all over the territory of Arabia, where most of the tribes were finally united, of their own free will, or as a result of military actions conducted under the banner of Islam. With time, the Islamic community umma became geographically more and more global and the geographical element lost its importance. Its place was taken by the concept of religious unity. In our times it is reflected not only by the change of the concept of umma (see later), but by the increasing number of Muslims in Europe and America as well.

The idea of umma as one and cohesive community is expressed in the notion itself. Carrying out the analysis of meaning of political; metaphors and general political language of Islam in his work The Political language of Islam, Bernard Lewis discusses the Quranic term umma "people", 
"community", as related to the Arabic word umm "mother", borrowed from Hebrew or Aramaic (Lewis, 1991, p. 17). Whereas William Montgomery Watt, in his work Islamic Thought points out that the term umma is rather derived from Hebrew ummā, which means "tribe" or simply "people". Whereas analysing the contents of the Quran, Watt concludes that umma has always been used in the context of ethnic, linguistic or religious communities, which are the subject of the God's plan of salvation (Watt, 2007, p. 10). The term refers also to ummat al-Islamiyah "Islamic community" and ummat al-mu 'minin "the community of believers", universally applied also in the context of Islamic politics. In the world of Islam, umma means first of all (though not only, see hereunder) the community of those, who were converted to the teachings of Muhammad, became the brotherly Muslim community, called "the nation of Muhammad" (umma Muhammad), for whom Islam developed political rules, and the entire system was of ethical-religious nature (Bielawski, 1973, p. 49). Jerzy Bielawski writes that this idea of mutual aid, brotherly solidarity and cooperation, which was treated as a religious as well as legal obligation, is present in every element of Muslim public and private law. It is due to the emphasized idea of collectivism, as in the doctrine of Islam an individual is perceived not so much as an individual, but more like a member of a community. Belonging to umma, Muslims fulfil fara'id, i.e. "responsibilities" towards the community, resulting from this idea of collectivism, whereas the right of an individual are treated rather as "entitlements" and are something else than fara'id (Tibi, 2009, p. 140-141). This "brotherly community" was a coherent being. There was always one and any splits resulted more from tribal nationalisms and then from dynastic succession disputes (Mez, 1981, p.17). Expressing the idea of unity, umma implements also the imperative of tawhid, i.e. the fundamental idea of the uniqueness of God present in the doctrine of Islam. It is also worthwhile to mention the fact that Islam itself is understood as a religion of unity (from Arabic slim, "reconciliation", "peace").

The conception of umma is not always interpreted exclusively in reference to a religious community. In the Quran itself, which not often mentioned, the concept refers to both, the entire community as well as to those who were not converted to Islam. It may result from the fact that the political structure of the Muslim society as well as of its subjects became with time more and more diversified, both ethnically and politically (Watt, 2007, p. 10). According to Watt, the more adequate notion, and much more often present in the Quran is the Arabic word qawm, i.e. "a tribe", "people", concerning a group linked by relationship ties, who form a real political and social unit. Presumably, this term was rather used in reference to the community of e.g. Jews in Medina, meaning not so much a religious group, as this was called mu'minūn, but rather an ethnic or language one. Therefore, even if the Quran calls "People of the Book" umma, it is understood in this sense. It might have resulted from the fact that both terms, umma and qawm did not differ much, really, and also from the fact that in the early 7th century, the concept of a tribe was still the centre of Arabic political thought (Watt, 2007, p. 11-12). Danecki observes, that attention should be focused on the fact that especially in the early centuries of Islam, because of the still respected tribal tradition of the ancient Arabs, the diversity between loyalty to one's own tribe and loyalty to umma was certainly complex. "A tribe was a lower structure, umma was a higher one, overlapping the tribe. It was, therefore, assumed that the way to umma leads through a tribe. 
So a stranger, who was not a member of an Islamized tribe wanted to become a Muslim, he or she had to submit to the tribal law. This meant that they had to enter into a wala - allegiance relation, submission to the laws of a given tribe, become its client (mawlā). Only then could they aspire to become members of umma, i.e. to become converted to Islam. To become a member of a tribe, it was not necessary to be converted to Islam (but one had to be a follower of another religion recognised by Islam, as Islam did not tolerate polytheists)" (Danecki, 2015, p. 129).

Umma is not a notion conveying directly the essence of a nation or a state in its Western meaning, though it is sometimes treated as their Islamic synonyms. It is also called a society, which in the general sense presented by social sciences is usually understood as a community of people occupying a definite territory, having regular models of social interactions, within the limits of which there is a definite kind of social structure and social relations, and it is usually characterised bysocial divisions, which eventually results in locating groups and/or individuals on different positions of social hierarchy, with a definite social status (Heywood, 2008, p. 241). Umma is a phenomenon typical exclusively for an Islamic community, based on specific criterions of sameness, acknowledged also as the basic Quranic concept of a political community. As it does not include geographical borders, and membership is closely connected with faith, it is difficult to acknowledge it to be a literal equivalent of a society as well. These expressions related to umma are used for the purpose of description, interpretation, probably because of lack of a more adequate terminology, but the differences should be borne in mind. The factor which determines communal nature here is the ideology of Islam and to this ideology did the notion of umma usually refer to in the first place. It should be noted, however, that the territorial dimension could also be an aspect of perceiving umma, since its existence was closely related to the sovereign existence of dār al-isläm, which is translated not only as "the world", but first of all as "the territory" of Islam. As a legal and political creation, umma had to have territory as well as a ruler, and it had to determine relations among groups, set relations among its citizens, whose stratification to a large extent was determined by their affiliation to Islam. In case of power, in Islam the head of the society and then of the state was Allah and Muhammad was the leader of the community and taught them in his name. As a Prophet, he did not have any successors, and after his death the power was exercised by caliphs. Though the office of a caliph is recognized to be both religious and political, in fact a caliph was neither a priest nor an ulama (ulamā, sing. âlim - a scholar, specializing in religious law). A caliph was an advocate of faith and its defender. He was described by the title of imam (in the sense of a leader), khalifah or a successor, and his political and military authority was called amir al-muminin, i.e "the leader of the faithful" (Lewis, 2003, p. 132). He was a spokesman of the faith and its defender, but he was not its teacher or commentator. Of course the questions of caliphs' powers and attitudes towards the caliphate changed along with its evolution, yet complexity of the idea of this authority in the Islamic country is a subject too extensive to be developed in this paper. It should be mentioned, however, that within Islam we discuss the issue of decentralization of any form of authority superior over the community of Muslims (Burgoński, Gierycz, 2014, p. 68), which results from the basic message of the Quran in this respect that the power belongs to Allah and those wielding it in his name are 
merely governors, substitutes. With reference to stratification of the Muslim society, there were divisions pertaining especially to the conquered territories, domestic civil and religious administration. A typical description of such stratification is presented, among others, by Lewis in his work mentioned above or John L. Esposito in his work Islam and Politics. In the first centuries of its development, Muslim society was divided into four major social classes. Arab Muslims, wielding special status, which they were entitled to as the Prophet's companions, constituted the elite. Their position was derived from the fact that they were the original founders of the umma. The next group was formed by mawālī, non-Arab converts to Islam. However, the term mawālī was also used in reference to those who were freed slaves, remaining in legally determined relations with their former master (Lewis, 1991, p. 66). The third group consisted of dhimmi, nonMuslims belonging to the protected groups, i.e. "People of the Book" and they were Christian and Jews. In return for the tax they paid, this group was entitled to follow their religion and leaders determined by their own religious laws. They were also protected by the Muslim army. The last group consisted of slaves, coming mainly from the ranks of prisoners of war captured during military operations. Muslims, Christians or Jews did not usually become slaves (Esposito, 1998, p. 11). For those who were recognised Islam, particularly to Arab Muslims, umma radically changed their lives, previous bold ties resulting from family-tribal relations were transformed to relations based on measures. According to Danecki, leaving umma, abandoning the community was consequently a kind of behaviour which was judged as morally wrong, as it led to breaking off the ties not only with co-brothers and tradition, but with God as well. In this respect, severing ties with umma was certainly more difficult than earlier severing ties with one's tribe, "This was the real strength of Islam as an idea connecting the faithful" (Danecki, 2015, p. 129). Umma also changed a lot in the geopolitical system, one can say that it was the key to open the road to the world for Arabs. According to Danecki, one of the most important factors creating favourable conditions for conquests was the completely new social organisation in the Arab Peninsula. Along with development of Islam, the Arab population was no longer a set of random, disorganised, often fighting among themselves tribes. It became united and well-organised umma which was not only a political alliance, but first of all it gave the sense of togetherness to the community under the banner of their own ideology (Danecki, 2015, p. 128). But it was not only umma that provided the driving force to Arab conquests and expansion, it was also the ideology of Islam, which "was the tool of social integration, provided Muslims with the sense of community transgressing tribal conflicts, although they still existed and survived until out time. Islam remained above those conflicts" (Danecki, 2015, p. 129).

The significance of umma changed only during the contemporary debate on Islam and existence of separate Muslim nations, which started using the term umma in this particular sense. Development of nationalistic ideologies, which caused the term to be used in many new meanings: in reference to all Arabs, Egyptian Muslims, or Iraqi Muslims, etc. influenced the change in perception of the umma (Hroub, 2010, p. 29-30). Although umma was both a religious and political community, its affiliation was defined only in religious categories. According to Watt, this leads to an interesting situation, where membership of a political community is defined on the basis of 
the profession of faith. The problem well illustrates equating umma with the state. Writing about The History of Development of Islam as a Socio-Political Doctrine, Hassan Ali Jamsheer draws our attention to the fact that in Islam there is a close relationship between umma and the state. Umma was the foundation for building new state order, and this is why it is difficult to separate them. Instead of aristocratic, family patterns of conduct (concerning mainly the Mecca families) collectivistic, communal objectives of a united community were to be created. The basis of unity was first of all Islam, defining on the assumption the character of a community, also called the state (Jamsheer, 2009, p. 88). "The state of Islam, or in other words the first Arab state in history, symbolised integration of the religious factor with the ethnic factor. In spite of the gap between the two elements during certain historical periods (e.g. at the time of the Ottoman Empire or as a result of joining the Muslim community by other ethnic groups and nations), the early Muslim unity and former integrated tradition occurred with different intensity in the early modern and contemporary times" (Jamsheer, 2009, p. 88).

Territorial expansion and military conquests, though they brought liberation of the infidel from paganism, had not only religious background. They implemented the process of transformation of the umma into an ideological and national unity, into an Islamic state. Its foundations were to be based on the Islamic patterns of the past traditions. It is the period of Muhammad's activity in Medina as well as the time of the rule of the first four rightful caliphs (rāshidūn) that is the historical, perfect model, "the golden age", for the contemporary Muslims. It gained special significance in the new political conditions that were created after the World War I, "as European powers divided the umma into territorially defined nation-states. Many Muslims in this period felt alienated from their vision of their past and besieged by the realities of contemporary circumstances" (Roberts, 2015, p. 135). Yet, the deeply rooted idea of Islam as a characteristic trait of the nation remained, though not in the form of umma including all the Muslims of the world. According to Nicholas P. Roberts, the ideal of umma became too abstract for most Muslims, to be implemented in everyday life. At present, Islam itself is the determinant of individual nations, homogeneous ethnic groups (Mandaville, 2014, p. 409; Roberts, 2015, p. 136). Whereas Bassam Tibi in his work Islam's Predicament with Modernity. Religious reform and cultural change maintains that the monolithic, particularly culturally, community is an invention of the twenty first century and it is "an imagined community in the politics of the world. It is a legitimization of Islamic internationalism, as well as of the political Islamic identity (Tibi, 2009, p. 149). Tibi writes that in out times, in Islam, the view on the ideal community, homogeneous umma managed by God, the perfect model of which was developed by the early centuries of Islam is seen in particular through the fact that all the different, local Islamic cultures share and maintain certain kind of "ancestral similarity", and on this basis they form a self-contained whole, which Tibi suggests should rather be given the name of "the umma civilisation" (Tibi, 2009, p. 149) .

Even when the Muslim world was divided among a number of empires, kingdoms and princedoms, starting from the times of the secession of the first Umayyad dynasty in favour of the Abbasid caliphate in the second half of the 8th century, the ideal of political unity of umma was maintained, at least among the Sunnites, through continuation of the institution of the caliphate 
among other things (Ayoob, 2008, pp. 31-32). Mohammed Ayoob in his work The Many Faces of Political Islam. Religion and Politics in the Muslim World writes that national states, which became common in the Muslim world in the 20th century were conceptually very different from the pre-modern, traditional for the Muslim world kingdoms and princedoms. It is exactly due to the established models concerning socio-political organisations "The ideal of nationalism posed a fundamental doctrinal and practical challenge to the concept of the umma. It did so by insisting that the nation-state, recognizing no superior and conceived as an organic entity, become the exclusive repository of its citizens' allegiance" (Ayoob, 2008, p. 32). Ayoob, like Roberts quoted above, also states that in spite of lack of full consensus between the idea of a nation and a state, the return to the conception of the united umma ceased to be real. What was left was the idea of a sovereign state and majority of the Muslims, including Islamists, assimilated its values and can easily function within the frames of a national state (Ayoob, 2008, p. 32).

The description of attitudes of contemporary Islamists and their approach to umma made by Lorenzo Vidino can be used as confirmation of the above. In an article about Islamism in Europe, Vidino states that European jihadists are strongly alienated from the European society, in which they were born and often are the second generation. No wonder that they are more connected with the European countries in which they have lived for many years than with the land of their ancestors. They are often unaware of the tradition or language of the old Islamic culture. This is why, Vidino writes, "while they are concerned about the plight of the global umma, they are equally if not more affected by events that take place in their own backyard. Seeing the world through the lenses of the most radical interpretations of Islam, they believe that Islam is under attack globally and that actions in defense of it can take place with equal justification and effectiveness in the West or in Muslim lands" (Vidino, 2015, p. 4).

Olivier Roy, in his work Globalized Islam. The Search for a New Ummah (2004) emphasized the phenomenon of "deterritorialization" of the Muslim political identity, which he recognized as the opposite of the analysed by some researchers idea of "transnational political Islam" or the "revived umma". Such views and similar ones aim in fact at capturing the essence of Muslim present day, in which the followers of Islam are situated between universalism and particular aspects of their own identity (Mandaville, 2014, p. 408). The current discussion, according to Peter Mandaville, concerning Muslim identity concerns first of all its political character and generally to the relations between Muslims and a state and a nation. In the current conditions, the relation is based, to a large extent, on the question concerning the fact whether the Muslims are the majority or the minority in a given country. According to Mandaville, studies on different Muslim regions and communities showed that with reference to the western countries, where Muslims live as religious minorities within political systems controlled by non-Muslims, questions arise as to whether Muslims can politically participate in such systems, and also how they should perceive the issues of their rights and duties concerning, for example citizenship in countries governed by non-Muslims (Mandaville, 2014, p. 408). The question of Muslim political identity in the countries where Muslims are the majority looks totally different. In this situation, the question does not concern the entitlement to participate in the rule carried out by non-Muslims, but rather the 
fact that Muslims, with the help of their religion, legitimize establishing Islamic political order. To sum up, one can add that in spite of the collapse of the traditional umma Islam is still part of the legitimization of power, politics and activities in this respect carried out by governments of the majority of the Muslim countries. It shows certain paradox in the era of national states, where politics is justified in the name of Islam and the character of government is shown as Islamic. According to Ayoob, on the one hand it enables the ruling authorities to maintain appearance of umma and on the other hand to maintain the appearance of continuity of the political tradition of Islam of the classical period. This is why the leaders of Muslim countries often present their governments as ancillary towards the interests of Islam (Ayoob, 2008, p. 33).

\section{References}

Ayoob, M. (2008). The Many Faces of Political Islam. Religion and Politics in the Muslim World. Michigan: Ann Arbor. Bielawski, J. (1973). Islam, religia państwa i prawa. Warszawa: Państwowe Wydawnictwo Wiedza Powszechna.

Błuszkowski, J. (2007). Naród w sensie etnicznym i politycznym. In: K.J. Wojtaszczyk, W. Jakubowski (eds.), Społeczeństwo i polityka. Podstawy nauk politycznych, Warszawa: Oficyna Wydawnicza Aspra.

Burgoński, P., Gierycz M. (red.) (2014). Religia i polityka. Zarys problematyki. Warszawa: Dom Wydawniczy Elipsa.

Danecki, J. (2015). Arabowie. Warszawa: Państwowy Instytut Wydawniczy.

El-Affendi, A. (2010). Umma, State and Movement. Events that Shaped the Modern Debate. In: K. Hroub (ed.), Political Islam. Context versus Ideology. London: London Middle East Institute at SOAS.

Esposito, J.L. (1998). Islam and Politics. New York: Syracuse University Press.

Heywood, A. (2008). Klucz do politologii. Najważniejsze ideologie, systemy, postaci. Warszawa: Wydawnictwo Naukowe PWN.

Heywood, A. (2008). Politologia. Warszawa: Wydawnictwo Naukowe PWN.

Hroub, K. (ed.) (2010), Political Islam. Context versus Ideology. London: London Middle East Institute at SOAS.

Jamsheer, H.A. (2009). Historia powstania islamu jako doktryny społeczno-politycznej. Warszawa: Wydawnictwo Akademickie Dialog.

Kitab, Sh. (2004). Wybrane zagadnienia klasycznego ustroju politycznego w islamie. Bydgoszcz: Wydawnictwo Akademii Bydgoskiej im. Kazimierza Wielkiego.

Koran (1986). Trans. J. Bielawski. Warszawa: Państwowy Instytut Wydawniczy.

Lewis, B. (2003). Muzutmański Bliski Wschód. Gdańsk: Wydawnictwo Marabut.

Lewis, B. (1991). The Political Language of Islam. Chicago-London: The University of Chicago Press.

Linjakumpu, A. (2012). Political Islam in the Global World. Southern Court: Ithaca Press.

Mandaville, P. (2014). Islam and Politics. New York: Routledge.

Mez, A. (1981). Renesans islamu. Warszawa: Państwowy Instytut Wydawniczy.

Roberts, N.P. (2015). Political Islam and the Invention of Tradition. Washington: New Academia Publishing.

Roy, O. (2004). Globalized Islam. The Search for a New Ummah. New York: Mass.

Wojtaszczyk, K.A., Jakubowski, W. (eds.)(2007). Społeczeństwo i polityka: podstawy nauk politycznych. Warszawa: Oficyna Wydawnicza ASPRA-JR.

Tibi, B. (2009). Islam's Predicament with Modernity. Religious reform and cultural change. London-New York: Routledge.

Vidino, L. (2015). Islamism in Europe, World Watch Research. Pobrano z: https://www.worldwatchmonitor.org/old-siteimgs-pdfs/3215322.pdf (27.03.2017).

Watt, W.M. (2007). Islamic Political Thought. Edinburgh: Edinburgh University Press.

Zenderowski, R. (2014). Islam. In: P. Burgoński, M. Gierycz (eds.), Religia i polityka. Zarys problematyki. Warszawa: Dom Wydawniczy Elipsa. 